\title{
Neurorestoration after stroke
}

\author{
Tej D. Azad, BA, Anand Veeravagu, MD, and Gary K. Steinberg, MD, PhD
}

Department of Neurosurgery, Stanford University School of Medicine, Stanford, California

\begin{abstract}
Recent advancements in stem cell biology and neuromodulation have ushered in a battery of new neurorestorative therapies for ischemic stroke. While the understanding of stroke pathophysiology has matured, the ability to restore patients' quality of life remains inadequate. New therapeutic approaches, including cell transplantation and neurostimulation, focus on reestablishing the circuits disrupted by ischemia through multidimensional mechanisms to improve neuroplasticity and remodeling. The authors provide a broad overview of stroke pathophysiology and existing therapies to highlight the scientific and clinical implications of neurorestorative therapies for stroke.
\end{abstract}

http://thejns.org/doi/abs/10.3171/2016.2.FOCUS15637

KEY WORDS optogenetics; exogenous stem cells; brain-computer interface; neuroplasticity

$\mathrm{S}$ TROKE is a devastating neurological condition and a leading cause of morbidity and mortality worldwide. This severe disease is responsible for roughly 1 in every 18 deaths in the United States. ${ }^{129}$ Nearly half of all stroke survivors require long-term care. ${ }^{145}$ The functional and cognitive disabilities of stroke survivors result in significant long-term health care costs. It was estimated that direct and indirect stroke-related costs resulted in a health care expenditure of $\$ 73.7$ billion in $2010 .{ }^{116}$

Currently, tissue plasminogen activator (tPA) is the only FDA-approved drug for acute ischemia. ${ }^{46}$ While tPA has markedly improved stroke care, it must be administered within a narrow time frame, limiting its clinical utility. Less than $10 \%$ of stroke patients can benefit from such treatments due, in large part, to late referral to the hospital and an inability to meet other eligibility criteria. ${ }^{2}$ Recently, endovascular therapies have also shown promise in treating acute stroke. After the acute period, stroke survivors face a myriad of challenges, including, but not limited to, hemiparesis and aphasia. ${ }^{55}$ While evidence supports the utility of rehabilitation efforts after acute stroke, ${ }^{150}$ complete neurological and physical recovery is rarely complete.

Thus, there is a distinct need for improved stroke recovery therapies. The profound vacuum in this field is particularly disappointing because evidence suggests that functional recovery is possible. ${ }^{115}$ In this review, we dis- cuss current stroke therapies and explore the burgeoning fields of cellular transplantation and neuromodulation as promising neurorestorative therapies for stroke (Fig. 1).

\section{Stroke Pathophysiology}

The cellular consequences of stroke include a complex and dynamic response of excitotoxicity, mitochondrial dysfunction, and oxidative stress..$^{53,112}$ While these pathways are well recognized in the promotion of neural and glial injury, stroke researchers have cultivated a more nuanced understanding of these mechanisms. Specifically, the pathways activated after ischemia also promote recovery; there exists duality in poststroke pathophysiology, which shifts depending on timing and the relative contribution of each constituent pathway.

Excitotoxicity and calcium $\left(\mathrm{Ca}^{2+}\right)$ overload are key contributors to the early stages of ischemic cell death. The lack of nutrients available to neurons after ischemia disrupts ionic gradients, resulting in excess release of excitatory amino acids-chiefly glutamate-driving an intracellular $\mathrm{Ca}^{2+}$ influx and setting in motion apoptotic and necrotic pathways. ${ }^{102}$

Mitochondria, reservoirs for proapoptotic and antiapoptotic proteins and cytochrome $\mathrm{C}$, experience dysfunction secondary to $\mathrm{Ca}^{2+}$ accumulation. ${ }^{103,114}$ Mitochondrial injury enables release of cytochrome $\mathrm{C}$, activating cas-

ABBREVIATIONS BCI = brain-computer interface; G-CSF = granulocyte colony-stimulating factor; MSC = mesenchymal stem cell; NPC = neural progenitor cell; NSC = neural stem cell; NT2N = Ntera2/D1 neuron-like; PSD-95 = postsynaptic density-95; RCT = randomized controlled trial; tDCS = transcranial direct current stimulation; TMS = transcranial magnetic stimulation; tPA = tissue plasminogen activator. 


\section{Stroke recovery}

\begin{tabular}{|c|c|c|c|c|}
\hline \multicolumn{2}{|c|}{ Acute treatment } & \multicolumn{3}{|c|}{ Chronic recovery } \\
\hline $\begin{array}{l}\text { Blood flow } \\
\text { restoration } \\
\text { - } \text { tPA } \\
\text { - Thrombectomy }\end{array}$ & $\begin{array}{l}\text { Neuro- } \\
\text { protection } \\
\text { - Hypothermia } \\
\text { - } \text { PSD-95 }\end{array}$ & $\begin{array}{l}\text { Cell-based } \\
\text { therapy } \\
\text { - Endogenous } \\
\text { stem cells } \\
\text { - Exogenous } \\
\text { stem cells } \\
\text { - Induced } \\
\text { stem cells }\end{array}$ & $\begin{array}{l}\text { Neuro- } \\
\text { modulation } \\
\text { - } \text { tDCS } \\
\text { - } \text { rTMS } \\
\text { - Cerebellar } \\
\text { - } \text { stimulation } \\
\text { - Vagal } \\
\text { - } \text { stimulation } \\
\text { - Optogeneti }\end{array}$ & $\begin{array}{l}\text { Brain-machine } \\
\text { interface } \\
\text { - Cortical } \\
\text { signals } \\
\text { - Spinal cord } \\
\text { signals }\end{array}$ \\
\hline
\end{tabular}

FIG. 1. Overview of neurorestorative modalities. rTMS = repetitive TMS; tDCS = transcranial direct current stimulation.

pase-dependent cellular death pathways. Reactive oxygen species, produced by mitochondria, have been implicated in reperfusion injury following ischemia. ${ }^{83}$

Oxidative and nitrosative stress, via free radicals, are also important mediators of ischemic injury and inhibitors of recovery. $\mathrm{Ca}^{2+}$ influx upregulates nitric oxide production, a byproduct of which is peroxynitrite, which can produce injury. ${ }^{75}$ Other contributors to oxidative stress include mitochondrial dysfunction ${ }^{83}$ and nicotinamide adenine dinucleotide phosphate-oxidase (NADPH) oxidase. ${ }^{15}$ There are 2 general hypotheses regarding the mechanism of oxidative stress-related injury. In the first scenario, the redox environment of cells modulates signal transduction cascades that tip the balance between prodeath and prosurvival pathways. ${ }^{34}$ In the second scenario, reactive oxygen species and perhaps reactive nitrogen species, including peroxynitrite, act directly as executioners of cell death. ${ }^{24}$ Other contributors to stroke pathophysiology include protein misfolding, also a result of excess $\mathrm{Ca}^{2+},{ }^{130}$ glial injury, ${ }^{108}$ and a broader proinflammatory response. ${ }^{76}$

In addition to the cellular insults incurred following stroke, neural circuits are also disrupted due to shifts in the excitation-inhibition balance in neural networks. In the setting of a long-term depression of inhibitory signals, cortical hyperexcitability peaks several weeks after stroke, though it can persist for months. ${ }^{18,135}$ Sustained increase in glutamate transmission following stroke also contributes to greater excitatory signals. ${ }^{23}$ Modulation of the tonic inhibition regulated by GABA(A) receptors has been shown to facilitate functional recovery in animal models. ${ }^{29}$ The unaffected contralesional hemisphere can also influence the excitatory state of the damaged hemisphere. ${ }^{113}$ Each component of the pathophysiological response following stroke, on both cellular and circuit levels, represents an opportunity for limiting initial injury and hastening recovery.

\section{Existing Stroke Therapies \\ Blood Flow Restoration}

Acute stroke therapy today largely consists of intravenous tPA, administered within a narrow time window. ${ }^{16,64}$ This window initially broadened to administration within
3 hours of symptomatic onset and was extended to 4.5 hours after a large trial demonstrated continued benefit of tPA at this time point..$^{63}$ In 2015 , endovascular therapies demonstrated a significant additive role in improving outcomes across 5 randomized controlled trials (RCTs) studying intraarterial thrombectomy. ${ }^{8,21,58,81,133}$ Given the diversity of strokes and patient-specific characteristics (e.g., collaterals and vasculature), patient selection may be critical for the ultimate success of these therapies. ${ }^{101} \mathrm{~A}$ key drawback of tPA and endovascular therapies is that the vast majority of stroke patients cannot get access to these treatments within the narrowly defined time limits. Beyond the acute time period, there is evidence that physical rehabilitation focused on the injured area is effective..$^{150}$ However, neurological recovery with physical rehabilitation is rarely complete-innovative approaches to enhance the body's endogenous regenerative abilities remain an opportunity for improvement.

\section{Neuroprotection}

The brain regions adjacent to the infarct, the ischemic penumbra, possess the greatest potential for poststroke recovery. ${ }^{22}$ Thus, limiting periinfarct damage is the objective of many neuro-protective treatments. Promising preclinical studies have focused on single pathways to achieve neuroprotection; however, the failure of clinical trials investigating neuroprotective strategies suggests that multiple pathways must be disrupted in humans to achieve similar success. ${ }^{42}$

Mild neurological hypothermia $\left(33^{\circ} \mathrm{C}\right)$, has demonstrated improved neurological outcomes for patients with global cerebral ischemia secondary to cardiac arrest and neonatal hypoxic-ischemic encephalopathy., ${ }^{9}, 139$ Mild hypothermia is currently being investigated as an acute stroke therapy, with trials to date proving the feasibility of this approach. ${ }^{121}$

Postsynaptic density-95 protein (PSD-95) represents an alternative neuroprotective target. This protein serves as an intermediary between NMDA receptors and the signaling pathways that produce the deleterious excitotoxic cascade. Inhibition of PSD-95 has been shown to reduce stroke volume in primates. ${ }^{32}$ A double-blind RCT demonstrated safety and improved neurological outcome and 
fewer acute infarcts in patients undergoing endovascular intracranial aneurysm repair who received a PSD-95 inhibitor. ${ }^{69}$

A third opportunity to enhance neuroprotection may exist in mediating the $\mathrm{Ca}^{2+}$ dysregulation observed after stroke. An acid-sensing ion channel, ASICla, is involved in the $\mathrm{Ca}^{2+}$ influx-inhibiting this channel may be neuroprotective. ${ }^{154} \mathrm{In}$ addition to the $\mathrm{Ca}^{2+}$ influx, failure of $\mathrm{Ca}^{2+}$ efflux contributes to the $\mathrm{Ca}^{2+}$ accumulation. Prostaglandin E2 EP1 receptors have been implicated in the failure of the $\mathrm{Na}^{+} / \mathrm{Ca}^{2+}$ exchanger during ischemia. Inhibition of these receptors has been shown to be neuroprotective. ${ }^{1,85}$ It remains unlikely that inhibition of any single stroke injury pathway will yield clinically meaningful neuroprotection. However, as researchers gain the ability to manipulate multiple recovery pathways, more effective neuroprotective therapies will emerge.

\section{Cellular Replacement Therapies}

Stem cells are undifferentiated cells that may specialize into multiple cell types and can self-renew. Stroke pathophysiology may be particularly amenable to stem cell therapy. After the initial injury and associated changes, there is no enduring neurodegenerative process inhibiting recovery. Two main lines of stem cell therapies for stroke have emerged: endogenous strategies focusing on facilitating mobilization, longevity, and production of existing neural stem cell and exogenous treatments in which cells are transplanted from another source into a patient.

\section{Endogenous Stem Cells}

The canonical niches for neural stem cells (NSCs) in the brain are the subventricular zone ${ }^{57}$ and dentate gyrus. ${ }^{3,43}$ Researchers have observed changes in migration patterns of neural progenitor cells (NPCs) following neurological injury, ${ }^{56}$ a key finding underlying endogenous stem cell therapeutic strategies. Furthermore, ischemia induces NPC proliferation ${ }^{118}$ and there is evidence of NPC differentiation into the predominantly injured cell type in a given region. ${ }^{6}$

Researchers have focused on neurogenesis-promoting pathways as potential methods to stimulate NPC proliferation. ${ }^{41,91}$ This approach is characterized by the use of regulatory factors that have been implicated in neurogenesis, such as glial-derived neurotrophic factor, brain-derived neurotrophic factor, vascular endothelial growth factor, granulocyte colony-stimulating factor (G-CSF), basic fibroblast growth factor-2, insulin-like growth factor-1, bone morphogenetic protein-7, epidermal growth factor, and transforming growth factor- $\alpha .{ }^{27,41,60,80,91,97,127,131,136,149,152}$ Alternative strategies to increase NPC proliferation include antiinflammatory drugs, noncoding RNAs, and hormones such as erythropoietin and growth hormone. ${ }^{71,137,151}$

A complementary approach strives to limit NPC death through administration of G-CSF and insulin-like growth factor-1 to alter key survival pathways. ${ }^{96}$ Inhibition of p53 and use of cyclosporine have also been studied as strategies to extend NPC survival. ${ }^{47,104}$ Ongoing clinical trials are investigating the dual roles of G-CSF, activation of endogenous bone marrow cells and neuroprotection, to determine efficacy in stroke recovery ${ }^{44,84} \mathrm{~A}$ recent review of 10 studies comprising 711 patients reported that G-CSF is safe and well tolerated. Moreover, G-CSF may foster functional recovery, as measured by the National Institutes of Health Stroke Scale and modified Rankin Scale scores. ${ }^{48}$

Methods that drive NPC proliferation to a clinically meaningful degree remain elusive and carry with them an innate risk of tumorigenesis. As endogenous stem cell strategies are investigated in clinical trials, the propensity of these cells to give rise to malignancies must be closely monitored.

\section{Exogenous Stem Cells}

Exogenous stem cell therapies can be stratified as immortalized cell lines, NPCs or NSCs, and bone marrow-derived progenitors and stromal cells. ${ }^{12}$ Immortalized cell lines are developed from tumor cells or from genetic manipulation. Ntera2/D1 neuron-like (NT2N) cells are derived from teratocarcinoma and differentiate into postmitotic neuron-like cells with addition of retinoic acid and mitotic inhibitors. ${ }^{122}$ NT2N cell transplantation has been shown to improve outcome in several preclinical models. ${ }^{66,132}$ ReNeuron's ReN001 cells, in which myc is genetically manipulated, have demonstrated dose-dependent recovery in stroke models in rodents ${ }^{144}$ and have been engineered to be immortalized only in the presence of tamoxifen to minimize the risk of tumor formation. ${ }^{143}$

NPCs are derived from embryonic and fetal tissue and can differentiate into astrocytes, neurons, and oligodendrocytes. ${ }^{52}$ Preclinical stroke models have revealed that NPCs can migrate to the injured brain regions and foster recovery. ${ }^{86,128,155}$ There is also evidence that NPCs integrate into existing tissue and take on neuronal characteristics, including expression of synaptic proteins, synapse formation, and electrophysiological properties. ${ }^{19,38,39}$

Progenitor cells, derived from bone marrow, umbilical cord blood, and adipose tissue, have demonstrated improvement in recovery in preclinical models. ${ }^{140} \mathrm{Sev}$ eral cell types are included in these strategies, and it appears that the mononuclear or marrow stromal cell component mediates recovery; however, it is not clear which specific subtype is responsible for improving functional outcomes. ${ }^{105}$ Multiple trials have been performed or are ongoing that use these exogenous stem cells (Table 1). ${ }^{98}$

The advent of induced pluripotent stem cells created a paradigm shift in cell-based therapy. The ability to differentiate somatic cells such as fibroblasts into pluripotent stem cells bypassed many of the concerns of traditional stem cell therapy. Further development has led to vector- and transgene-free techniques to derive induced pluripotent stem cells that improve functional outcome after brain ischemia. ${ }^{110}$ It is now possible to produce neural cells directly from mouse or human fibroblasts using transcription factors, bypassing pluripotent stages, a development that may have marked clinical significance. ${ }^{117}$

\section{Delivery}

Peripheral delivery techniques, whether intravenous or intraarterial, rely on inflammatory modulation or para- 
TABLE 1. Current clinical trials of exogenous stem or progenitor cells for stroke recovery

\begin{tabular}{|c|c|c|c|c|}
\hline Trial ID No. & Phase & Cell Type & Delivery Mechanism & Status \\
\hline NCT00473057 & I & BMMNC & IA or IV & Complete, no reported results \\
\hline NCT02065778 & I & BMMNC & IT & Complete, no reported results \\
\hline NCT01501773 & II & BMMNC & IV & Safe, feasible \\
\hline NCT01849887 & I & BMMNC & IV & Not currently recruiting \\
\hline NCT00859014 & I & BMMNC & IV & Safe, feasible \\
\hline NCT02425670 & II & BMMNC & IV & Safe, feasible, no efficacy benefit \\
\hline NCT01832428 & $1 / I 1$ & BMMNC & IT & Recruiting \\
\hline NCT02245698 & I & BMMNC & IT & Recruiting \\
\hline NCT02290483 & II & BMMNC & $\mathrm{IA}$ & Recruiting \\
\hline India, 2011 & $1 / I I$ & BMMNC & IV & Safe, feasible, improved neurological outcomes \\
\hline NCT01436487 & II & Multistem & IV & Safe, feasible, no efficacy benefit \\
\hline NCT02117635 & II & CTX0E03, NSC & IC & Safe, improved neurological outcomes \\
\hline NCT01151124 & 1 & CTX0E03, NSC & IC & Not currently recruiting \\
\hline NCT01453829 & $1 / \|$ & ASC & $\mathrm{IA}$ & Not currently recruiting \\
\hline NCT01091701 & $\mathrm{I} / \mathrm{II}$ & MSC & IV & Not currently recruiting \\
\hline South Korea, 2010 & $|/| \mid$ & MSC & IV & Safe, feasible, improved neurological outcomes \\
\hline NCT00875654 & II & MSC & IV & Not currently recruiting \\
\hline NCT01297413 & $|/| \mid$ & MSC & IV & Recruiting \\
\hline NCT01678534 & $1 / I 1$ & MSC & IV & Not currently recruiting \\
\hline Japan, 2011 & I & MSC & IV & Safe, feasible, decreased infarct volume \\
\hline NCT01714176 & 1 & MSC & IC & Recruiting \\
\hline NCT01716481 & III & MSC & IV & Recruiting \\
\hline NCT0146172 & II & MSC & IV & Not currently recruiting \\
\hline NCT01922908 & $|/ I|$ & MSC & IV & Not currently recruiting \\
\hline NCT01468064 & $1 / I 1$ & MSC, EPC & IV & Recruiting \\
\hline NCT00761982 & $1 / I I$ & CD34+ & IA & Safe, feasible, increased $\beta$-NGF \\
\hline NCT00950521 & II & CD34+ & IC & Complete, no reported results \\
\hline NCT00535197 & $1 / I 1$ & CD34+ & IA & Safe, feasible, reduced infarct volume \\
\hline NCT01518231 & I & CD34+ & IA & Recruiting \\
\hline NCT01438593 & I & CD34+ & IC & Not currently recruiting \\
\hline NCT01310114 & II & PDC & IV & Stopped by sponsor \\
\hline NCT01327768 & I & OEC & IC & Recruiting \\
\hline NCT01287936 & $1 / I \mid$ & SB623 & IC & Safe, improved neurological outcomes \\
\hline BB-IND 7082 & II & NT2N & IC & Safe, feasible, improved neurological outcomes in secondary end points \\
\hline BB-IND 7082 & I & NT2N & IC & Safe, improved neurological outcomes \\
\hline
\end{tabular}

$\mathrm{ASC}=$ adipose-derived stromal cells; $\mathrm{BMMNC}=$ bone marrow mononuclear cells; $\mathrm{EPC}=$ endothelial progenitor cells; $\mathrm{IA}=$ intra-arterial; $I \mathrm{IC}=$ intracranial; $\mathrm{IT}=$ intrathecal; IV = intravenous; NGF = nerve growth factor; NT2N = tetracarcinoma cell-derived neurons; $\mathrm{OEC}=$ olfactory ensheathing cells; PDC = placenta-derived stem cells; SB623 = human mesenchymal stromal cells .

crine effects of the cells on the postischemic brain. ${ }^{61,78}$ However, invasive transplantation, particularly intracerebral delivery, of stem cells provides for transplantation of large cell numbers at or near to the site and facilitates the trophic effects of stem cells. Advanced delivery methods are under development, including bioengineered polymers, to enhance stem cell survival and efficacy. Inert polymer matrices, such as hydrogels and particles, have been described for stem cell delivery. ${ }^{148,157}$

There are relative benefits and drawbacks for each delivery strategy. Intravenous administration is likely the safest and easy to perform but exposes cells to filtration by peripheral organs, such as the spleen and liver. Intraarterial transfusions enable improved targeting of cells with fewer cells being lost to other tissues, but these transfusions require arterial access. Intraventricular delivery increases safety risks inherent to accessing the ventricular system, but it provides closer proximity to the infarct. Intracerebral transplantation allows for direct delivery to perilesional tissue, but it is the most invasive technique.

Development of multimodal molecular imaging techniques will be invaluable to identify optimal stem cell 
delivery methods and to monitor transplanted cells. One approach utilizes superparamagnetic iron oxide-based MRI of grafted cells to observe migration in experimental stroke models. ${ }^{62,72,156}$ Our group combined this approach with reporter gene-based molecular imaging techniques. We were able to monitor the fate and function of grafted cells in real time using multimodal MRI and bioluminescent imaging. ${ }^{39}$ Clinical translation of molecular imaging techniques will enable an improved understanding of which delivery strategies are best able to deliver healthy stem cells in clinically meaningful doses.

\section{Clinical Trials}

To date, clinical trials of cell transplantation for stroke have focused on assessing safety and efficacy. A significant concern for any stem cell therapy is risk of tumor formation-careful classification and understanding of the underlying biology are critical to avoid such adverse effects. ${ }^{77}$ Immortalized NT2N cell lines were the first human cells used in a Phase I trial. Cells were implanted into the infarcts of 12 patients $0.5-6$ years following a basal ganglia stroke..$^{93}$ No major adverse events occurred, and significant functional improvement was observed in this initial study. A subsequent Phase II trial with these NT2N cells recapitulated the safety of cellular transplantation though the primary outcome, motor function, was not met. ${ }^{92}$ An open-label, single-blinded RCT using mesenchymal stem cells (MSCs) demonstrated significant functional improvement based on the modified Rankin Scale score with no difference in adverse events, and multiple other trials have shown safety and feasibility. ${ }^{10,11,95}$ Furthermore, RCTs using bone marrow mononuclear cells have also shown safety and feasibility. ${ }^{51,111,134} \mathrm{~A}$ phase $1 / 2 \mathrm{~A}$ study of transplanted human modified bone marrow-derived stromal cells has demonstrated safety and feasibility with direct intracerebral transplantation $0.5-5$ years poststroke with improvement in neurological outcomes. ${ }^{142}$ Interim results from the first trial of NSCs for ischemic stroke, an open-label, dose-escalation study, have shown no adverse events and improved functional outcomes in 11 patients with follow-up between 9 and 24 months. ${ }^{82}$ Demonstration of efficacy in double-blinded RCTs is needed, but numerous clinical trials are underway (Table 1) to determine whether cell-based therapy will become the next modality of restorative stroke therapy.

\section{Neuromodulation}

Neuromodulation is a well-established disruption of the excitatory-inhibitory balance in neural networks following ischemic stroke. ${ }^{18,23,135}$ Modulation of the tonic inhibition regulated by receptors of inhibitory neurotransmitters has been shown to improve functional recovery in animal models. ${ }^{29}$ Improved regulation and a well-developed understanding of how the excitatory-inhibitory balance is disrupted after stroke is critical to designing therapeutic approaches for stroke recovery.

Multiple neuromodulation techniques have been investigated to facilitate motor recovery after stroke. To date, however, both noninvasive transcranial magnetic stimulation (TMS) and invasive techniques have demonstrated
TABLE 2. Clinical studies of neuromodulatory techniques for stroke recovery

\begin{tabular}{|c|c|c|c|}
\hline Authors \& Year & $\begin{array}{c}\text { No. of } \\
\text { Patients }\end{array}$ & Intervention & Outcome \\
\hline Levy et al., 2008 & 24 & EECS & Safe \& effective \\
\hline Brown et al., 2008 & 10 & EECS & Safe \\
\hline Levy et al., 2016 & 164 & EECS & $\begin{array}{l}\text { No difference from } \\
\text { control }\end{array}$ \\
\hline Kim et al., 2006 & 15 & rTMS & Improved motor function \\
\hline $\begin{array}{l}\text { Takeuchi et al., } \\
2005\end{array}$ & 20 & rTMS & Improved motor function \\
\hline Khedr et al., 2005 & 26 & rTMS & Improved motor function \\
\hline Fregni et al., 2006 & 15 & rTMS & Improved motor function \\
\hline Malcolm et al., 2007 & 19 & rTMS & $\begin{array}{l}\text { No difference from } \\
\text { control }\end{array}$ \\
\hline Seniów et al., 2012 & 40 & rTMS & $\begin{array}{l}\text { No difference from } \\
\text { control }\end{array}$ \\
\hline Talelli et al., 2012 & 41 & rTMS & $\begin{array}{l}\text { No difference from } \\
\text { control }\end{array}$ \\
\hline $\begin{array}{l}\text { Cunningham et al., } \\
2015\end{array}$ & 12 & tDCS & Proof of concept \\
\hline Boggio et al., 2007 & 9 & tDCS & Improved motor function \\
\hline Hesse et al., 2011 & 96 & tDCS & $\begin{array}{l}\text { No difference from } \\
\text { control }\end{array}$ \\
\hline
\end{tabular}

EECS = epidural electrical stimulation; rTMS = repetitive TMS.

limited clinical efficacy. ${ }^{88,146}$ Epidural stimulation of the cortex showed promising initial clinical results, ${ }^{17,99}$ but long-term benefits have not been supported when assessed in a large-scale clinical trial (Table 2). ${ }^{100,124}$

\section{Cortical Stimulation}

Cortical stimulation represents a key strategy to restore the excitatory-inhibitory balance of the damaged brain and reorganize neural circuitry to enhance poststroke recovery. Noninvasive methods (e.g., TMS and transcranial direct current stimulation [tDCS] ) and invasive methods (e.g., implantable epidural electrodes) have been explored. ${ }^{141,153}$

High-frequency TMS increases cortical excitability and low-frequency stimulation decreases excitability. These characteristics have been exploited to increase functional improvement of the affected extremity. ${ }^{31,87,89}$ Stimulation of the contralesional hemisphere after stroke is an area of sustained interest; it can be recruited to improve recovery, but also imposes increased inhibition on the affected hemisphere. ${ }^{50,113}$ Stimulation with tDCS has met similar outcomes, with improvement after stroke during therapy. ${ }^{73}$ However, Cochrane reviews of TMS and tDCS concluded that further investigation is required to determine either technique's role in stroke recovery. ${ }^{45,65} \mathrm{~A}$ double-blinded pilot RCT to evaluate the long-term efficacy of tDCS found evidence that stimulation of higher motor areas can help recruit adaptation of the contralesional hemisphere in patients with greater ipsilesional injury. ${ }^{36,125}$ In sum, the 
promise of noninvasive neuromodulation for stroke recovery, while demonstrating early promise,,$^{13,74}$ has not borne out in larger clinical trials (Table 2).68,107,123,126,138,147

Invasive cortical stimulation offers the advantage of greater stimulus delivery duration at a more precise location. Upper-extremity recovery is a significant limitation following stroke, with only $20 \%$ of patients reaching full recovery at 6 months. ${ }^{94}$ Preclinical and pilot human studies demonstrated improved recovery and safety with invasive stimulation techniques..$^{90,99}$ A clinical trial was initiated based on these findings,${ }^{67}$ evaluating invasive cortical stimulation in conjunction with rehabilitation, but was ultimately discontinued by the sponsoring company (Northstar Neuroscience). A better understanding of the proper stimulation sites and paradigms should facilitate translation of this technique to the clinical arena.

\section{Cerebellar Stimulation}

TMS has also been applied to the cerebellum. Recently, Bonnì et al. applied TMS over the lateral cerebellum of patients with ataxia due to chronic posterior circulation ischemic stroke. The authors observed both neurophysiological and clinical improvements. ${ }^{14}$ Invasive cerebellar stimulation has also been studied. Deep brain stimulation of the cerebello-thalamo-cortical pathway, specifically of the lateral cerebellar nucleus, ${ }^{119}$ has been shown in preclinical rodent models to modulate cerebral cortex excitability $^{7}$ and improve postischemia motor recovery. ${ }^{106}$ More recently, chronic cerebellar DBS demonstrated promotion of long-term potentiation, neuroplasticity, and reparative reorganization. ${ }^{33}$

\section{Vagal Stimulation}

Given the observation that intensive training has been shown to facilitate a range of neuroplastic brain events, ${ }^{20}$ researchers hypothesize that vagal nerve stimulation can enhance neuroplasticity and promote reorganization of neural networks. ${ }^{35}$ A recent RCT of vagal nerve stimulation to augment upper-limb rehabilitation following stroke was shown to be safe and feasible. ${ }^{40}$ Further prospective studies are necessary to evaluate the efficacy of this modality.

\section{Optogenetics}

After stroke, plasticity, both structural and functional, can occur in periinfarct regions. Neuronal activity in surviving cells can release activity-dependent factors that rewire neural connections and enhance recovery. Regulating the excitability in these neurons offers a path toward functional recovery. ${ }^{25}$ Until recently, the ability to discretely stimulate precise neural circuitry remained beyond the grasp of neuroscientists.

The flourishing field of optogenetics may offer a solution to this roadblock because it modulates specific cell types with high precision and spatiotemporal resolution. ${ }^{49}$ Optogenetics is a technique in which specific wavelengths of light are used to control living cells, particularly neurons, that have been genetically modified to express lightsensitive ion channels. ${ }^{59,109}$ This technique has fundamentally extended the abilities of neuroscientists to manipulate neural circuits. In the context of stroke, optogenetic techniques revealed that even small ischemic injuries and depression in excitability could lead to relatively large effects on motor circuits. ${ }^{4,25}$

Optogenetics also has potential as a therapeutic and restorative modality. Optogenetics have been shown to mitigate seizures; similar strategies could be used to mediate neural excitability following stroke. ${ }^{120}$ Given the ability to stimulate specific neural circuits, optogenetics could be used to precisely manipulate pathways, in particular, brain regions, to facilitate recovery. Our group has investigated whether optogenetics could be used to selectively improve functional outcomes following stroke. ${ }^{26}$ The authors used transgenic mice expressing channelrhodopsin (ChR2) under a neuronal promoter to selectively increase neuronal activity in the ipsilesional primary motor cortex, after inducing stroke. They found that stimulated mice performed better on functional tests, gained weight more quickly, and demonstrated improved cerebral blood flow. Moreover, neurotrophin expression was observed in the contralesional motor cortex. This was the first study to demonstrate that optogenetics can be used to promote functional recovery after stroke.

Optogenetic techniques also present an opportunity to interrogate and augment cellular transplantation therapies. While NSC transplantation therapy has demonstrated promise, as discussed above, the mechanisms underlying functional recovery remain opaque. A recent preclinical study from our group sought to use optogenetics to better understand the mechanisms by which NSCs graft into the damaged brain and modulate local circuits. Stimulation of engrafted ChR2-expressing NSCs revealed upregulation of genes involved in neurotransmission, neuronal differentiation, axonal guidance, and synaptic plasticity. Furthermore, genes involved in the inflammatory response were downregulated. Most notably, optogenetic stimulation promoted stroke recovery. ${ }^{37}$ A current drawback of optogenetics is that it requires genetic alteration, limiting its clinical applications. However, clinical gene therapy is making marked progress, and applying optogenetics to modulate recovery pathways may eventually be translated into clinical care.

\section{Brain-Computer Interface}

Brain-computer interface (BCI) research strives to restore motor control to individuals who have lost this ability. The applications of this burgeoning field to stroke recovery are evident. Because ischemia is usually an isolated event, and not a neurodegenerative process, many of the neural networks unaffected by the infarct remain whole, providing a basis for BCI therapy.

Movements are often controlled by deciphering cortical activity to produce movements in primates, ${ }^{28}$ and, more recently, cortical signals recorded through high-density microelectrode arrays and electrocorticography grids allowed paralyzed patients the ability to control robotic limbs and computer cursors..$^{30,54,70,79}$

Closed-loop systems have begun to explore the ability of primates to control limb function by utilizing cortical signals to stimulate spinal circuits to induce upper limb movements. ${ }^{158}$ Noninvasive methods such as electroen- 
cephalography-based systems have also been implemented in neurorehabilitation programs, and, as these technologies are developed further, they may replace implantable arrays. ${ }^{5}$ These methods, however, are still limited by complications in long-term interfaces between tissue and electronics and the ability to accurately decipher integrated neural outputs of the cortex. As the ability to interpret cortical signals and robotics becomes more sophisticated, BCIs offer exciting potential to restore function to patients with hemiplegia or language impairment from stroke.

\section{Conclusions}

The burden of stroke is felt by patients and their families across the globe. While acute therapies exist, the complex pathophysiology of this disease has hindered efforts to augment functional recovery. Neurorestoration must remain a critical objective for stroke research; cell-based therapies and neuromodulation are the 2 fields that have demonstrated the greatest promise in promoting recovery. Through further focused study and aggressive translation efforts, neurorestoration will manifest a new frontier in stroke care.

\section{References}

1. Abe T, Kunz A, Shimamura M, Zhou P, Anrather J, Iadecola $\mathrm{C}$ : The neuroprotective effect of prostaglandin E2 EP1 receptor inhibition has a wide therapeutic window, is sustained in time and is not sexually dimorphic. J Cereb Blood Flow Metab 29:66-72, 2009

2. Allen NB, Kaltenbach L, Goldstein LB, Olson DM, Smith $\mathrm{EE}$, Peterson ED, et al: Regional variation in recommended treatments for ischemic stroke and TIA: Get with the Guidelines - Stroke 2003-2010. Stroke 43:1858-1864, 2012

3. Anderson DJ: Stem cells and pattern formation in the nervous system: the possible versus the actual. Neuron 30:1935,2001

4. Anenberg E, Arstikaitis P, Niitsu Y, Harrison TC, Boyd JD, Hilton BJ, et al: Ministrokes in channelrhodopsin-2 transgenic mice reveal widespread deficits in motor output despite maintenance of cortical neuronal excitability. J Neurosci 34:1094-1104, 2014

5. Ang KK, Chua KS, Phua KS, Wang C, Chin ZY, Kuah CW, et al: A randomized controlled trial of EEG-based motor imagery brain-computer interface robotic rehabilitation for stroke. Clin EEG Neurosci 46:310-320, 2015

6. Arvidsson A, Collin T, Kirik D, Kokaia Z, Lindvall O: Neuronal replacement from endogenous precursors in the adult brain after stroke. Nat Med 8:963-970, 2002

7. Baker KB, Schuster D, Cooperrider J, Machado AG: Deep brain stimulation of the lateral cerebellar nucleus produces frequency-specific alterations in motor evoked potentials in the rat in vivo. Exp Neurol 226:259-264, 2010

8. Berkhemer OA, Fransen PS, Beumer D, van den Berg LA, Lingsma HF, Yoo AJ, et al: A randomized trial of intraarterial treatment for acute ischemic stroke. N Engl J Med 372:11-20, 2015

9. Bernard SA, Gray TW, Buist MD, Jones BM, Silvester W, Gutteridge G, et al: Treatment of comatose survivors of outof-hospital cardiac arrest with induced hypothermia. N Engl J Med 346:557-563, 2002

10. Bhasin A, Srivastava MV, Kumaran SS, Mohanty S, Bhatia $\mathrm{R}$, Bose S, et al: Autologous mesenchymal stem cells in chronic stroke. Cerebrovasc Dis Extra 1:93-104, 2011

11. Bhasin A, Srivastava MV, Mohanty S, Bhatia R, Kumaran
SS, Bose S: Stem cell therapy: a clinical trial of stroke. Clin Neurol Neurosurg 115: 1003-1008, 2013

12. Bliss TM, Andres RH, Steinberg GK: Optimizing the success of cell transplantation therapy for stroke. Neurobiol Dis 37:275-283, 2010

13. Boggio PS, Nunes A, Rigonatti SP, Nitsche MA, PascualLeone A, Fregni F: Repeated sessions of noninvasive brain DC stimulation is associated with motor function improvement in stroke patients. Restor Neurol Neurosci 25:123129, 2007

14. Bonnì S, Ponzo V, Caltagirone C, Koch G: Cerebellar theta burst stimulation in stroke patients with ataxia. Funct Neurol 29:41-45, 2014

15. Brennan AM, Suh SW, Won SJ, Narasimhan P, Kauppinen TM, Lee H, et al: NADPH oxidase is the primary source of superoxide induced by NMDA receptor activation. Nat Neurosci 12:857-863, 2009

16. Brott TG, Haley EC Jr, Levy DE, Barsan W, Broderick J, Sheppard GL, et al: Urgent therapy for stroke. Part I. Pilot study of tissue plasminogen activator administered within 90 minutes. Stroke 23:632-640, 1992

17. Brown JA, Lutsep HL, Weinand M, Cramer SC: Motor cortex stimulation for the enhancement of recovery from stroke: a prospective, multicenter safety study. Neurosurgery 62 (Suppl 2):853-862, 2008

18. Buchkremer-Ratzmann I, August M, Hagemann G, Witte OW: Electrophysiological transcortical diaschisis after cortical photothrombosis in rat brain. Stroke 27:1105-1111, 1996

19. Bühnemann C, Scholz A, Bernreuther C, Malik CY, Braun $\mathrm{H}$, Schachner M, et al: Neuronal differentiation of transplanted embryonic stem cell-derived precursors in stroke lesions of adult rats. Brain 129:3238-3248, 2006

20. Buma FE, Lindeman E, Ramsey NF, Kwakkel G: Functional neuroimaging studies of early upper limb recovery after stroke: a systematic review of the literature. Neurorehabil Neural Repair 24:589-608, 2010

21. Campbell BC, Mitchell PJ, Kleinig TJ, Dewey HM, Churilov L, Yassi N, et al: Endovascular therapy for ischemic stroke with perfusion-imaging selection. N Engl J Med 372:1009-1018, 2015

22. Carmichael ST, Archibeque I, Luke L, Nolan T, Momiy J, Li S: Growth-associated gene expression after stroke: evidence for a growth-promoting region in peri-infarct cortex. Exp Neurol 193:291-311, 2005

23. Centonze D, Rossi S, Tortiglione A, Picconi B, Prosperetti C, De Chiara V, et al: Synaptic plasticity during recovery from permanent occlusion of the middle cerebral artery. Neurobiol Dis 27:44-53, 2007

24. Chan PH: Reactive oxygen radicals in signaling and damage in the ischemic brain. J Cereb Blood Flow Metab 21:2-14, 2001

25. Cheng MY, Wang EH, Steinberg GK: Optogenetic approaches to study stroke recovery. ACS Chem Neurosci 5:1144-1145, 2014

26. Cheng MY, Wang EH, Woodson WJ, Wang S, Sun G, Lee AG, et al: Optogenetic neuronal stimulation promotes functional recovery after stroke. Proc Natl Acad Sci U S A 111:12913-12918, 2014

27. Chou J, Harvey BK, Chang CF, Shen H, Morales M, Wang Y: Neuroregenerative effects of BMP7 after stroke in rats. J Neurol Sci 240:21-29, 2006

28. Churchland MM, Cunningham JP, Kaufman MT, Ryu SI, Shenoy KV: Cortical preparatory activity: representation of movement or first cog in a dynamical machine? Neuron 68:387-400, 2010

29. Clarkson AN, Huang BS, Macisaac SE, Mody I, Carmichael ST: Reducing excessive GABA-mediated tonic inhibition promotes functional recovery after stroke. Nature 468:305309, 2010 
30. Collinger JL, Wodlinger B, Downey JE, Wang W, TylerKabara EC, Weber DJ, et al: High-performance neuroprosthetic control by an individual with tetraplegia. Lancet 381:557-564, 2013

31. Conforto AB, Anjos SM, Saposnik G, Mello EA, Nagaya EM, Santos W Jr, et al: Transcranial magnetic stimulation in mild to severe hemiparesis early after stroke: a proof of principle and novel approach to improve motor function. $\mathbf{J}$ Neurol 259:1399-1405, 2012

32. Cook DJ, Teves L, Tymianski M: Treatment of stroke with a PSD-95 inhibitor in the gyrencephalic primate brain. Nature 483:213-217, 2012

33. Cooperrider J, Furmaga H, Plow E, Park HJ, Chen Z, Kidd $\mathrm{G}$, et al: Chronic deep cerebellar stimulation promotes longterm potentiation, microstructural plasticity, and reorganization of perilesional cortical representation in a rodent model. J Neurosci 34:9040-9050, 2014

34. Crack PJ, Taylor JM: Reactive oxygen species and the modulation of stroke. Free Radic Biol Med 38:1433-1444, 2005

35. Cramer SC, Sur M, Dobkin BH, O’Brien C, Sanger TD, Trojanowski JQ, et al: Harnessing neuroplasticity for clinical applications. Brain 134:1591-1609, 2011

36. Cunningham DA, Varnerin N, Machado A, Bonnett C, Janini D, Roelle $\mathrm{S}$, et al: Stimulation targeting higher motor areas in stroke rehabilitation: A proof-of-concept, randomized, double-blinded placebo-controlled study of effectiveness and underlying mechanisms. Restor Neurol Neurosci 33:911-926, 2015

37. Daadi MM, Klausner JQ, Bajar B, Goshen I, Lee-Messer C, Lee SY, et al: Optogenetic stimulation of neural grafts enhances neurotransmission and downregulates the inflammatory response in experimental stroke model. Cell Transplant [epub ahead of print], 2015

38. Daadi MM, Lee SH, Arac A, Grueter BA, Bhatnagar R, Maag AL, et al: Functional engraftment of the medial ganglionic eminence cells in experimental stroke model. Cell Transplant 18:815-826, 2009

39. Daadi MM, Li Z, Arac A, Grueter BA, Sofilos M, Malenka $\mathrm{RC}$, et al: Molecular and magnetic resonance imaging of human embryonic stem cell-derived neural stem cell grafts in ischemic rat brain. Mol Ther 17:1282-1291, 2009

40. Dawson J, Pierce D, Dixit A, Kimberley TJ, Robertson M, Tarver B, et al: Safety, feasibility, and efficacy of vagus nerve stimulation paired with upper-limb rehabilitation after ischemic stroke. Stroke 47:143-150, 2016

41. Dempsey RJ, Sailor KA, Bowen KK, Türeyen K, Vemuganti R: Stroke-induced progenitor cell proliferation in adult spontaneously hypertensive rat brain: effect of exogenous IGF-1 and GDNF. J Neurochem 87:586-597, 2003

42. Dirnagl U, Iadecola C, Moskowitz MA: Pathobiology of ischaemic stroke: an integrated view. Trends Neurosci 22:391-397, 1999

43. Doetsch F, Petreanu L, Caille I, Garcia-Verdugo JM, Alvarez-Buylla A: EGF converts transit-amplifying neurogenic precursors in the adult brain into multipotent stem cells. Neuron 36:1021-1034, 2002

44. Dunac A, Frelin C, Popolo-Blondeau M, Chatel M, Mahagne MH, Philip PJ: Neurological and functional recovery in human stroke are associated with peripheral blood CD34+ cell mobilization. J Neurol 254:327-332, 2007

45. Elsner B, Kugler J, Pohl M, Mehrholz J: Transcranial direct current stimulation (tDCS) for improving function and activities of daily living in patients after stroke. Cochrane Database Syst Rev 11:CD009645, 2013

46. Emberson J, Lees KR, Lyden P, Blackwell L, Albers G, Bluhmki E, et al: Effect of treatment delay, age, and stroke severity on the effects of intravenous thrombolysis with alteplase for acute ischaemic stroke: a meta-analysis of individual patient data from randomised trials. Lancet 384:1929-1935, 2014

47. Erlandsson A, Lin CH, Yu F, Morshead CM:

Immunosuppression promotes endogenous neural stem and progenitor cell migration and tissue regeneration after ischemic injury. Exp Neurol 230:48-57, 2011

48. Fan ZZ, Cai HB, Ge ZM, Wang LQ, Zhang XD, Li L, et al: The efficacy and safety of granulocyte colony-stimulating factor for patients with stroke. J Stroke Cerebrovasc Dis 24:1701-1708, 2015

49. Fenno L, Yizhar O, Deisseroth K: The development and application of optogenetics. Annu Rev Neurosci 34:389412, 2011

50. Fregni F, Boggio PS, Valle AC, Rocha RR, Duarte J, Ferreira MJ, et al: A sham-controlled trial of a 5-day course of repetitive transcranial magnetic stimulation of the unaffected hemisphere in stroke patients. Stroke 37:2115-2122, 2006

51. Friedrich MA, Martins MP, Araújo MD, Klamt C, Vedolin $\mathrm{L}$, Garicochea B, et al: Intra-arterial infusion of autologous bone marrow mononuclear cells in patients with moderate to severe middle cerebral artery acute ischemic stroke. Cell Transplant 21 (Suppl 1):S13-S21, 2012

52. Gage FH: Mammalian neural stem cells. Science 287:14331438,2000

53. George PM, Steinberg GK: Novel stroke therapeutics: unraveling stroke pathophysiology and its impact on clinical treatments. Neuron 87:297-309, 2015

54. Gilja V, Pandarinath C, Blabe $\mathrm{CH}$, Nuyujukian P, Simeral JD, Sarma AA, et al: Clinical translation of a high-performance neural prosthesis. Nat Med 21:1142-1145, 2015

55. Go AS, Mozaffarian D, Roger VL, Benjamin EJ, Berry JD, Blaha MJ, et al: Executive summary: heart disease and stroke statistics - 2014 update: a report from the American Heart Association. Circulation 129:399-410, 2014

56. Goings GE, Sahni V, Szele FG: Migration patterns of subventricular zone cells in adult mice change after cerebral cortex injury. Brain Res 996:213-226, 2004

57. Goldman SA, Nottebohm F: Neuronal production, migration, and differentiation in a vocal control nucleus of the adult female canary brain. Proc Natl Acad Sci U S A 80:2390-2394, 1983

58. Goyal M, Demchuk AM, Menon BK, Eesa M, Rempel $\mathrm{JL}$, Thornton J, et al: Randomized assessment of rapid endovascular treatment of ischemic stroke. N Engl J Med 372:1019-1030, 2015

59. Gradinaru V, Mogri M, Thompson KR, Henderson JM, Deisseroth K: Optical deconstruction of parkinsonian neural circuitry. Science 324:354-359, 2009

60. Guerra-Crespo M, Gleason D, Sistos A, Toosky T, Solaroglu I, Zhang JH, et al: Transforming growth factor-alpha induces neurogenesis and behavioral improvement in a chronic stroke model. Neuroscience 160:470-483, 2009

61. Guzman R, Choi R, Gera A, De Los Angeles A, Andres RH, Steinberg GK: Intravascular cell replacement therapy for stroke. Neurosurg Focus 24 (3-4):E15, 2008

62. Guzman R, Uchida N, Bliss TM, He D, Christopherson KK, Stellwagen D, et al: Long-term monitoring of transplanted human neural stem cells in developmental and pathological contexts with MRI. Proc Natl Acad Sci U S A 104:1021110216, 2007

63. Hacke W, Kaste M, Bluhmki E, Brozman M, Dávalos A, Guidetti D, et al: Thrombolysis with alteplase 3 to 4.5 hours after acute ischemic stroke. N Engl J Med 359:1317-1329, 2008

64. Haley EC Jr, Levy DE, Brott TG, Sheppard GL, Wong MC, Kongable GL, et al: Urgent therapy for stroke. Part II. Pilot study of tissue plasminogen activator administered 91-180 minutes from onset. Stroke 23:641-645, 1992 
65. Hao Z, Wang D, Zeng Y, Liu M: Repetitive transcranial magnetic stimulation for improving function after stroke. Cochrane Database Syst Rev 5:CD008862, 2013

66. Hara K, Yasuhara T, Maki M, Matsukawa N, Masuda T, Yu SJ, et al: Neural progenitor NT2N cell lines from teratocarcinoma for transplantation therapy in stroke. Prog Neurobiol 85:318-334, 2008

67. Harvey RL, Winstein CJ: Design for the Everest randomized trial of cortical stimulation and rehabilitation for arm function following stroke. Neurorehabil Neural Repair 23:32-44, 2009

68. Hesse S, Waldner A, Mehrholz J, Tomelleri C, Pohl M, Werner C: Combined transcranial direct current stimulation and robot-assisted arm training in subacute stroke patients: an exploratory, randomized multicenter trial. Neurorehabil Neural Repair 25:838-846, 2011

69. Hill MD, Martin RH, Mikulis D, Wong JH, Silver FL, Terbrugge KG, et al: Safety and efficacy of NA-1 in patients with iatrogenic stroke after endovascular aneurysm repair (ENACT): a phase 2, randomised, double-blind, placebocontrolled trial. Lancet Neurol 11:942-950, 2012

70. Hochberg LR, Bacher D, Jarosiewicz B, Masse NY, Simeral JD, Vogel J, et al: Reach and grasp by people with tetraplegia using a neurally controlled robotic arm. Nature 485:372-375, 2012

71. Hoehn BD, Palmer TD, Steinberg GK: Neurogenesis in rats after focal cerebral ischemia is enhanced by indomethacin. Stroke 36:2718-2724, 2005

72. Hoehn M, Küstermann E, Blunk J, Wiedermann D, Trapp T, Wecker S, et al: Monitoring of implanted stem cell migration in vivo: a highly resolved in vivo magnetic resonance imaging investigation of experimental stroke in rat. Proc Natl Acad Sci U S A 99:16267-16272, 2002

73. Hummel F, Celnik P, Giraux P, Floel A, Wu WH, Gerloff C, et al: Effects of non-invasive cortical stimulation on skilled motor function in chronic stroke. Brain 128:490-499, 2005

74. Hummel FC, Celnik P, Pascual-Leone A, Fregni F, Byblow WD, Buetefisch CM, et al: Controversy: Noninvasive and invasive cortical stimulation show efficacy in treating stroke patients. Brain Stimulat 1:370-382, 2008

75. Iadecola $C$ : Bright and dark sides of nitric oxide in ischemic brain injury. Trends Neurosci 20:132-139, 1997

76. Iadecola C, Anrather J: The immunology of stroke: from mechanisms to translation. Nat Med 17:796-808, 2011

77. Jandial R, Snyder EY: A safer stem cell: on guard against cancer. Nat Med 15:999-1001, 2009

78. Janowski M, Walczak P, Date I: Intravenous route of cell delivery for treatment of neurological disorders: a metaanalysis of preclinical results. Stem Cells Dev 19:5-16, 2010

79. Jarosiewicz B, Sarma AA, Bacher D, Masse NY, Simeral JD, Sorice B, et al: Virtual typing by people with tetraplegia using a self-calibrating intracortical brain-computer interface. Sci Transl Med 7:313ra179, 2015

80. Jin K, Zhu Y, Sun Y, Mao XO, Xie L, Greenberg DA: Vascular endothelial growth factor (VEGF) stimulates neurogenesis in vitro and in vivo. Proc Natl Acad Sci U S A 99:11946-11950, 2002

81. Jovin TG, Chamorro A, Cobo E, de Miquel MA, Molina CA, Rovira A, et al: Thrombectomy within 8 hours after symptom onset in ischemic stroke. N Engl J Med 372:2296-2306, 2015

82. Kalladka D, Sinden J, Pollock K, Smith W, McLean J, Dunn L, et al: PISCES - a phase I trial of CTX0E03 human neural stem cells in ischaemic stroke: interim results. Cerebrovasc Dis 37 (Suppl 1):49, 2014 (Abstract)

83. Kalogeris T, Bao Y, Korthuis RJ: Mitochondrial reactive oxygen species: a double edged sword in ischemia/reperfusion vs preconditioning. Redox Biol 2:702-714, 2014
84. Kawada H, Takizawa S, Takanashi T, Morita Y, Fujita J, Fukuda K, et al: Administration of hematopoietic cytokines in the subacute phase after cerebral infarction is effective for functional recovery facilitating proliferation of intrinsic neural stem/progenitor cells and transition of bone marrowderived neuronal cells. Circulation 113:701-710, 2006

85. Kawano T, Anrather J, Zhou P, Park L, Wang G, Frys KA, et al: Prostaglandin E2 EP1 receptors: downstream effectors of COX-2 neurotoxicity. Nat Med 12:225-229, 2006

86. Kelly S, Bliss TM, Shah AK, Sun GH, Ma M, Foo WC, et al: Transplanted human fetal neural stem cells survive, migrate, and differentiate in ischemic rat cerebral cortex. Proc Natl Acad Sci U S A 101:11839-11844, 2004

87. Khedr EM, Ahmed MA, Fathy N, Rothwell JC: Therapeutic trial of repetitive transcranial magnetic stimulation after acute ischemic stroke. Neurology 65:466-468, 2005

88. Kim YH, You SH, Ko MH, Park JW, Lee KH, Jang SH, et al: Repetitive transcranial magnetic stimulation-induced corticomotor excitability and associated motor skill acquisition in chronic stroke. Stroke 37:1471-1476, 2006

89. Kirton A, Chen R, Friefeld S, Gunraj C, Pontigon AM, Deveber G: Contralesional repetitive transcranial magnetic stimulation for chronic hemiparesis in subcortical paediatric stroke: a randomised trial. Lancet Neurol 7:507-513, 2008

90. Kleim JA, Bruneau R, VandenBerg P, MacDonald E, Mulrooney R, Pocock D: Motor cortex stimulation enhances motor recovery and reduces peri-infarct dysfunction following ischemic insult. Neurol Res 25:789-793, 2003

91. Kobayashi T, Ahlenius H, Thored P, Kobayashi R, Kokaia Z, Lindvall O: Intracerebral infusion of glial cell linederived neurotrophic factor promotes striatal neurogenesis after stroke in adult rats. Stroke 37:2361-2367, 2006

92. Kondziolka D, Steinberg GK, Wechsler L, Meltzer CC, Elder E, Gebel J, et al: Neurotransplantation for patients with subcortical motor stroke: a phase 2 randomized trial. J Neurosurg 103:38-45, 2005

93. Kondziolka D, Wechsler L, Goldstein S, Meltzer C, Thulborn KR, Gebel J, et al: Transplantation of cultured human neuronal cells for patients with stroke. Neurology 55:565569,2000

94. Kwakkel G, Kollen BJ, van der Grond J, Prevo AJ: Probability of regaining dexterity in the flaccid upper limb: impact of severity of paresis and time since onset in acute stroke. Stroke 34:2181-2186, 2003

95. Lee JS, Hong JM, Moon GJ, Lee PH, Ahn YH, Bang OY: A long-term follow-up study of intravenous autologous mesenchymal stem cell transplantation in patients with ischemic stroke. Stem Cells 28:1099-1106, 2010

96. Lee SR, Kim HY, Rogowska J, Zhao BQ, Bhide P, Parent $\mathrm{JM}$, et al: Involvement of matrix metalloproteinase in neuroblast cell migration from the subventricular zone after stroke. J Neurosci 26:3491-3495, 2006

97. Leker RR, Soldner F, Velasco I, Gavin DK, AndroutsellisTheotokis A, McKay RD: Long-lasting regeneration after ischemia in the cerebral cortex. Stroke 38: 153-161, 2007

98. Lemmens R, Steinberg GK: Stem cell therapy for acute cerebral injury: what do we know and what will the future bring? Curr Opin Neurol 26:617-625, 2013

99. Levy R, Ruland S, Weinand M, Lowry D, Dafer R, Bakay $\mathrm{R}$ : Cortical stimulation for the rehabilitation of patients with hemiparetic stroke: a multicenter feasibility study of safety and efficacy. J Neurosurg 108:707-714, 2008

100. Levy RM, Harvey RL, Kissela BM, Winstein CJ, Lutsep HL, Parrish TB, et al: Epidural electrical stimulation for stroke rehabilitation: results of the prospective, multicenter, randomized, single-blinded Everest Trial. Neurorehabil Neural Repair 30:107-119, 2016

101. Liebeskind DS, Jahan R, Nogueira RG, Zaidat OO, Saver JL: Impact of collaterals on successful revascularization in 
Solitaire FR with the intention for thrombectomy. Stroke 45:2036-2040, 2014

102. Lipton P: Ischemic cell death in brain neurons. Physiol Rev 79:1431-1568, 1999

103. Liu X, Kim CN, Yang J, Jemmerson R, Wang X: Induction of apoptotic program in cell-free extracts: requirement for dATP and cytochrome c. Cell 86:147-157, 1996

104. Luo Y, Kuo CC, Shen H, Chou J, Greig NH, Hoffer BJ, et al: Delayed treatment with a p53 inhibitor enhances recovery in stroke brain. Ann Neurol 65:520-530, 2009

105. Ma F, Morancho A, Montaner J, Rosell A: Endothelial progenitor cells and revascularization following stroke. Brain Res 1623:150-159, 2015

106. Machado AG, Baker KB, Schuster D, Butler RS, Rezai A: Chronic electrical stimulation of the contralesional lateral cerebellar nucleus enhances recovery of motor function after cerebral ischemia in rats. Brain Res 1280:107-116, 2009

107. Malcolm MP, Triggs WJ, Light KE, Gonzalez Rothi LJ, Wu $\mathrm{S}$, Reid K, et al: Repetitive transcranial magnetic stimulation as an adjunct to constraint-induced therapy: an exploratory randomized controlled trial. Am J Phys Med Rehabil 86:707-715, 2007

108. Matute C, Domercq M, Pérez-Samartín A, Ransom BR: Protecting white matter from stroke injury. Stroke 44:12041211, 2013

109. Miller G: Optogenetics. Shining new light on neural circuits. Science 314:1674-1676, 2006

110. Mohamad O, Drury-Stewart D, Song M, Faulkner B, Chen D, Yu SP, et al: Vector-free and transgene-free human iPS cells differentiate into functional neurons and enhance functional recovery after ischemic stroke in mice. PLoS One 8:e64160, 2013

111. Moniche F, Gonzalez A, Gonzalez-Marcos JR, Carmona M, Piñero P, Espigado I, et al: Intra-arterial bone marrow mononuclear cells in ischemic stroke: a pilot clinical trial. Stroke 43:2242-2244, 2012

112. Moskowitz MA, Lo EH, Iadecola C: The science of stroke: mechanisms in search of treatments. Neuron 67:181-198, 2010

113. Murase N, Duque J, Mazzocchio R, Cohen LG: Influence of interhemispheric interactions on motor function in chronic stroke. Ann Neurol 55:400-409, 2004

114. Murphy AN, Fiskum G, Beal MF: Mitochondria in neurodegeneration: bioenergetic function in cell life and death. $\mathbf{J}$ Cereb Blood Flow Metab 19:231-245, 1999

115. Murphy TH, Corbett D: Plasticity during stroke recovery: from synapse to behaviour. Nat Rev Neurosci 10:861-872, 2009

116. Noorian AR, Bryant K, Aiken A, Nicholson AD, Edwards $\mathrm{AB}$, Markowski MP, et al: Initial experience with upfront arterial and perfusion imaging among ischemic stroke patients presenting within the 4.5 -hour time window. J Stroke Cerebrovasc Dis 23:220-224, 2014

117. Pang ZP, Yang N, Vierbuchen T, Ostermeier A, Fuentes DR, Yang TQ, et al: Induction of human neuronal cells by defined transcription factors. Nature 476:220-223, 2011

118. Parent JM, Vexler ZS, Gong C, Derugin N, Ferriero DM: Rat forebrain neurogenesis and striatal neuron replacement after focal stroke. Ann Neurol 52:802-813, 2002

119. Park HJ, Furmaga H, Cooperrider J, Gale JT, Baker KB, Machado AG: Modulation of Cortical Motor Evoked Potential After Stroke During Electrical Stimulation of the Lateral Cerebellar Nucleus. Brain Stimulat 8:1043-1048, 2015

120. Paz JT, Davidson TJ, Frechette ES, Delord B, Parada I, Peng K, et al: Closed-loop optogenetic control of thalamus as a tool for interrupting seizures after cortical injury. Nat Neurosci 16:64-70, 2013

121. Piironen K, Tiainen M, Mustanoja S, Kaukonen KM,
Meretoja A, Tatlisumak T, et al: Mild hypothermia after intravenous thrombolysis in patients with acute stroke: a randomized controlled trial. Stroke 45:486-491, 2014

122. Pleasure SJ, Lee VM: NTera 2 cells: a human cell line which displays characteristics expected of a human committed neuronal progenitor cell. J Neurosci Res 35:585-602, 1993

123. Plow EB, Arora P, Pline MA, Binenstock MT, Carey JR: Within-limb somatotopy in primary motor cortex - revealed using fMRI. Cortex 46:310-321, 2010

124. Plow EB, Carey JR, Nudo RJ, Pascual-Leone A: Invasive cortical stimulation to promote recovery of function after stroke: a critical appraisal. Stroke 40:1926-1931, 2009

125. Plow EB, Cunningham DA, Beall E, Jones S, Wyant A, Bonnett $\mathrm{C}$, et al: Effectiveness and neural mechanisms associated with tDCS delivered to premotor cortex in stroke rehabilitation: study protocol for a randomized controlled trial. Trials 14:331, 2013

126. Plow EB, Cunningham DA, Varnerin N, Machado A: Rethinking stimulation of the brain in stroke rehabilitation: why higher motor areas might be better alternatives for patients with greater impairments. Neuroscientist 21:225240,2015

127. Popa-Wagner A, Stöcker K, Balseanu AT, Rogalewski A, Diederich K, Minnerup J, et al: Effects of granulocytecolony stimulating factor after stroke in aged rats. Stroke 41:1027-1031, 2010

128. Reubinoff BE, Itsykson P, Turetsky T, Pera MF, Reinhartz E, Itzik A, et al: Neural progenitors from human embryonic stem cells. Nat Biotechnol 19:1134-1140, 2001

129. Roger VL, Go AS, Lloyd-Jones DM, Benjamin EJ, Berry JD, Borden WB, et al: Heart disease and stroke statistics - 2012 update: a report from the American Heart Association. Circulation 125:e2-e220, 2012

130. Roussel BD, Kruppa AJ, Miranda E, Crowther DC, Lomas DA, Marciniak SJ: Endoplasmic reticulum dysfunction in neurological disease. Lancet Neurol 12:105-118, 2013

131. Sairanen M, Lucas G, Ernfors P, Castrén M, Castrén E: Brain-derived neurotrophic factor and antidepressant drugs have different but coordinated effects on neuronal turnover, proliferation, and survival in the adult dentate gyrus. J Neurosci 25:1089-1094, 2005

132. Saporta S, Borlongan CV, Sanberg PR: Neural transplantation of human neuroteratocarcinoma (hNT) neurons into ischemic rats. A quantitative dose-response analysis of cell survival and behavioral recovery. Neuroscience 91:519525,1999

133. Saver JL, Goyal M, Bonafe A, Diener HC, Levy EI, Pereira VM, et al: Solitaire ${ }^{\mathrm{TM}}$ with the Intention for Thrombectomy as Primary Endovascular Treatment for Acute Ischemic Stroke (SWIFT PRIME) trial: protocol for a randomized, controlled, multicenter study comparing the Solitaire revascularization device with IV tPA with IV tPA alone in acute ischemic stroke. Int J Stroke 10:439-448, 2015

134. Savitz SI, Misra V, Kasam M, Juneja H, Cox CS Jr, Alderman S, et al: Intravenous autologous bone marrow mononuclear cells for ischemic stroke. Ann Neurol 70:5969,2011

135. Schiene K, Bruehl C, Zilles K, Qü M, Hagemann G, Kraemer M, et al: Neuronal hyperexcitability and reduction of GABAA-receptor expression in the surround of cerebral photothrombosis. J Cereb Blood Flow Metab 16:906-914, 1996

136. Schneider A, Krüger C, Steigleder T, Weber D, Pitzer C, Laage R, et al: The hematopoietic factor G-CSF is a neuronal ligand that counteracts programmed cell death and drives neurogenesis. J Clin Invest 115:2083-2098, 2005

137. Schouten M, Buijink MR, Lucassen PJ, Fitzsimons CP: New neurons in aging brains: molecular control by small non-coding RNAs. Front Neurosci 6:25, 2012 
138. Seniów J, Bilik M, Leśniak M, Waldowski K, Iwański S, Członkowska A: Transcranial magnetic stimulation combined with physiotherapy in rehabilitation of poststroke hemiparesis: a randomized, double-blind, placebo-controlled study. Neurorehabil Neural Repair 26:1072-1079, 2012

139. Shankaran S, Pappas A, McDonald SA, Vohr BR, Hintz SR, Yolton K, et al: Childhood outcomes after hypothermia for neonatal encephalopathy. N Engl J Med 366:2085-2092, 2012

140. Shen LH, Li Y, Chen J, Zacharek A, Gao Q, Kapke A, et al: Therapeutic benefit of bone marrow stromal cells administered 1 month after stroke. J Cereb Blood Flow Metab 27:6-13, 2007

141. Steel A, Song S, Bageac D, Knutson KM, Keisler A, Saad $\mathrm{ZS}$, et al: Shifts in connectivity during procedural learning after motor cortex stimulation: A combined transcranial magnetic stimulation/functional magnetic resonance imaging study. Cortex 74:134-148, 2016

142. Steinberg GK, Kondziolka D, Schwartz NE, Wechsler L, Lunsford LD, Coburn ML, et al: A novel phase 1/2A study of intraparenchymal transplantation of human modified bone marrow derived cells in patients with stable ischemic stroke. Stroke 45:A149, 2014 (Abstract)

143. Stroemer P, Hope A, Patel S, Pollock K, Sinden J: Development of a human neural stem cell line for use in recovery from disability after stroke. Front Biosci 13:22902292, 2008

144. Stroemer P, Patel S, Hope A, Oliveira C, Pollock K, Sinden $\mathrm{J}$ : The neural stem cell line CTX0E03 promotes behavioral recovery and endogenous neurogenesis after experimental stroke in a dose-dependent fashion. Neurorehabil Neural Repair 23:895-909, 2009

145. Sturm JW, Donnan GA, Dewey HM, Macdonell RA, Gilligan AK, Srikanth V, et al: Quality of life after stroke: the North East Melbourne Stroke Incidence Study (NEMESIS). Stroke 35:2340-2345, 2004

146. Takeuchi N, Chuma T, Matsuo Y, Watanabe I, Ikoma K: Repetitive transcranial magnetic stimulation of contralesional primary motor cortex improves hand function after stroke. Stroke 36:2681-2686, 2005

147. Talelli P, Wallace A, Dileone M, Hoad D, Cheeran B, Oliver $\mathrm{R}$, et al: Theta burst stimulation in the rehabilitation of the upper limb: a semirandomized, placebo-controlled trial in chronic stroke patients. Neurorehabil Neural Repair 26:976-987, 2012

148. Teng YD, Lavik EB, Qu X, Park KI, Ourednik J, Zurakowski D, et al: Functional recovery following traumatic spinal cord injury mediated by a unique polymer scaffold seeded with neural stem cells. Proc Natl Acad Sci U S A 99:3024-3029, 2002

149. Teramoto T, Qiu J, Plumier JC, Moskowitz MA: EGF amplifies the replacement of parvalbumin-expressing striatal interneurons after ischemia. J Clin Invest 111:1125-1132, 2003

150. Veerbeek JM, van Wegen E, van Peppen R, van der Wees
PJ, Hendriks E, Rietberg M, et al: What is the evidence for physical therapy poststroke? A systematic review and metaanalysis. PLoS One 9:e87987, 2014

151. Wang L, Zhang Z, Wang Y, Zhang R, Chopp M: Treatment of stroke with erythropoietin enhances neurogenesis and angiogenesis and improves neurological function in rats. Stroke 35: 1732-1737, 2004

152. Wittko IM, Schänzer A, Kuzmichev A, Schneider FT, Shibuya M, Raab S, et al: VEGFR-1 regulates adult olfactory bulb neurogenesis and migration of neural progenitors in the rostral migratory stream in vivo. J Neurosci 29:8704-8714, 2009

153. Woods AJ, Antal A, Bikson M, Boggio PS, Brunoni AR, Celnik P, et al: A technical guide to tDCS, and related non-invasive brain stimulation tools. Clin Neurophysiol 127:1031-1048, 2016

154. Zeng WZ, Liu DS, Duan B, Song XL, Wang X, Wei D, et al: Molecular mechanism of constitutive endocytosis of Acid-sensing ion channel $1 \mathrm{a}$ and its protective function in acidosis-induced neuronal death. J Neurosci 33:7066-7078, 2013

155. Zhang SC, Wernig M, Duncan ID, Brüstle O, Thomson JA: In vitro differentiation of transplantable neural precursors from human embryonic stem cells. Nat Biotechnol 19:1129-1133, 2001

156. Zhang ZG, Jiang Q, Zhang R, Zhang L, Wang L, Zhang L, et al: Magnetic resonance imaging and neurosphere therapy of stroke in rat. Ann Neurol 53:259-263, 2003

157. Zhong J, Chan A, Morad L, Kornblum HI, Fan G, Carmichael ST: Hydrogel matrix to support stem cell survival after brain transplantation in stroke. Neurorehabil Neural Repair 24:636-644, 2010

158. Zimmermann JB, Jackson A: Closed-loop control of spinal cord stimulation to restore hand function after paralysis. Front Neurosci 8:87, 2014

\section{Disclosures}

Dr. Steinberg serves on the Medtronic Neuroscience Strategic Advisory Board and is a consultant for Qool Therapeutics.

\section{Author Contributions}

Conception and design: all authors. Acquisition of data: Azad. Analysis and interpretation of data: Azad, Veeravagu. Drafting the article: Azad, Veeravagu. Critically revising the article: all authors. Reviewed submitted version of manuscript: all authors. Administrative/technical/material support: Steinberg, Azad. Study supervision: Steinberg.

\section{Correspondence}

Gary K. Steinberg, Department of Neurosurgery, Stanford University School of Medicine, 300 Pasteur Dr., Stanford, CA 94305. email: gsteinberg@stanford.edu. 